\title{
The impact of depopulation in urban areas on the development of built-up suburban areas - the case of Poznań and Skórzewo
}

\author{
Piotr Zierke \\ Poznan University of Technology, Department of Architecture, Institute of Architecture and Physical Planning \\ e-mail:piotr.zierke@put.poznan.pl
}

\begin{abstract}
The Poznań Conurbation is a place where the suburbanisation process is appearing. The spatial transformation of suburban areas indicates that the application of research-based solutions, which in theory are supposed to reduce unfavourable trends, in practice appears to be a complicated task. Problems that remain unresolved for many years, as well as mistakes that often cancel efforts to solve these problems, are the obvious confirmation of that thesis. An important factor, which affects the poor spatial situation in suburban areas, is the lack of central urban planning indices. Although each municipality that is part of the Poznań Conurbation has its own up-to-date statutory land use policy study and other documents defining the local spatial planning policy, their records frequently contain solutions that are not beneficial to the public interest or sustainable development. Problems that are mentioned in producing them, as well as the unachieved aspirations and needs of space users, contribute to increased criticism of complex urban structures, while the strong position of developers in suburban areas raises the question as to whether the area of land dedicated to new buildings, especially residential ones is not too excessive when compared with current needs. This paper presents the results of research that concerns the relationship between the depopulation of Poznan and the increase of the built-up area in the neighbouring village of Skórzewo, which is a place of massive development of residential buildings and rapidly developing enterprises. The aim of this research is to introduce a tool for a more precise prediction of future spatial development in suburban areas.
\end{abstract}

Keywords: suburbanisation, urban sprawl, Poznań Conurbation

submitted: April 2017

reviewed: September 2017

accepted: November 2017

\section{Introduction}

The Poznan Conurbation is a place where the phenomenon of suburbanisation is occurring. Although several phases of suburbanisation have taken place in the history of urban planning (the first one dates back to the beginning of the $19^{\text {th }}$ century (Benevolo 2000)), Polish cities began to experience spatial changes after the political transformation of 1989, which up until that moment had been particularly characteristic of the United States and Western Europe. Statistical data which indicates 1990 as the year in which Poznan had its largest number of inhabitants confirm the above observation. Since that moment, based on the data provided by the Polish Statistical Office, we observe a gradual decrease in the city's population.

The process of migration from central districts of cities to the suburbs has been - due to its long history - examined in detail by both foreign and Polish scientists. The works of P. Hall (1971), L. H. Klaassen, W. T. M. Molle \& J. Paelinck (1981) as well as L. van den Berg et al. (1982) that developed the concepts of cycles and phases of transformation of urban regions, have been particularly important in the context of examining the phenomenon of suburbanisation. P. Hall (1971: 118-119) carried out his research using a model that distinguished between the main 'core' of the city, its 'ring' and the hinterland. He suggested a four-phase model of city development, which began with a phase of centralisation and ended first with relative and finally with absolute decentralisation. This model was developed by L. H. Klaassen et al. (1981). Van den Berg (1982: 36) has defined four urban development cycles - Urbanisation, Suburbanisation, Disurbanisation and Reurbanisation. L. H. Klassen and L. van den Berg agreed that reurbanisation was possible and 'must be brought about fast and resolutely' (Berg et al. 1982: 44), although 'in 
fact it rarely leads to the restoration of the population density in the core that existed before the major transformations had begun' (Beim 2009: 36). In the context of this paper it is worth mentioning that in the 1980s simple models appeared for examining the relationships between migration and the size of settlements. Such examinations were developed e.g. by A. J. Fielding (1982: 8-10) and used the analysis of urbanisation and counter-urbanisation that was 'taking place in a settlement system where there exists a negative relationship between migratory growth rate and urban status' (Champion 2001: 145).

In parallel with the development of knowledge on the phenomenon of suburbanisation, attempts were made to counteract it. Simple models describing settlement networks had already been developed in the $19^{\text {th }}$ century e.g. by J. H. von Thünen (1826). However, it was the development of mathematical techniques in the mid- $20^{\text {th }}$ century that led to the breakthrough in modelling urban transformations. Scientists started to use cellular automata, which were disseminated in the 1980s through the works of S. Wolfram $(1983,1986)$. Further development in science has resulted in the introduction of new forecasting techniques such as artificial neural networks, multi-agent systems, or ant colony optimalisation algorithms, which could be also combined with other methods to create complex mathematical hybrids (Chong 2004). The first Polish simulation of transformations in urban areas was performed in the Warsaw conurbation by P. Werner (2005), while M. Beim (2009) has proposed a hybrid model combining cellular automata with artificial neural networks to forecast the suburbanisation process in the Poznań conurbation.

It is worth mentioning that as a result of long-term research work, the causes of another process called urban sprawl were also defined. This phenomenon related to a suburbanisation process that was described as 'a new pattern of suburban spatial model that is deliberately ignoring historical urban conditions and human experience in this regard' (Duany, Plater-Zyberk \& Speck 2001: 3). This phenomenon, which is also present in the Poznań Conurbation, can be characterised by the massive development of modern resi- dential housing areas that are separated from the old urban structure of villages, discrete shopping centres and business parks, a poor infrastructure and a road network that gives priority to car traffic (Beim 2009: 38).

Moreover, various initiatives are being taken to limit unfavourable trends in the development of suburban areas. In recent years, proposals to introduce sustainability principles have become popular in suburbs (Heberle, Opp 2008), and new terms and trends such as 'walkability' (that are used to measure how friendly urban spaces are for pedestrians) were even introduced (Hutabarat Lo 2009).

Unfortunately, observations of changes that were taking place in the zones of Poznan Conurbation that were studied seem to confirm that the proposed solutions to problems are not always welcomed by the residents of such areas and people who are responsible for their development. This is confirmed by still unresolved problems and recurring mistakes, which often thwart attempts at their solution. The most important challenges relating to the suburbanisation process in the Poznan Conurbation in recent years have included the reduction of the degradation of the suburban landscape (such landscape often consists of complexes of chaotic developments with irrational functional structure); the restoration of due value to public spaces; the reconstruction of social relationships and natural structures; and the alleviation of the congestion on the roads (Bonenberg 2011: 11). An important issue that stems from the failure to follow the principles of sustainability in suburbia is the reduction of arable land, which is usually replaced by new residential developments (Bonenberg 2011: 9), as well as a lack of staging in the activation of new areas designated for development in local plans. As a consequence, the development of new built-up areas is many times determined by random divisions of ownership after the status of farm land has changed, rather than by analyses supported by the principles of urban planning (Zierke 2016). This leads to spatial chaos and the aggravation of the above-mentioned problems (Fig. 1).

One of the causes of spatial problems (resulting in social, infrastructural, and ecological issues) has been the lack of central urban planning indices for more than thirty years

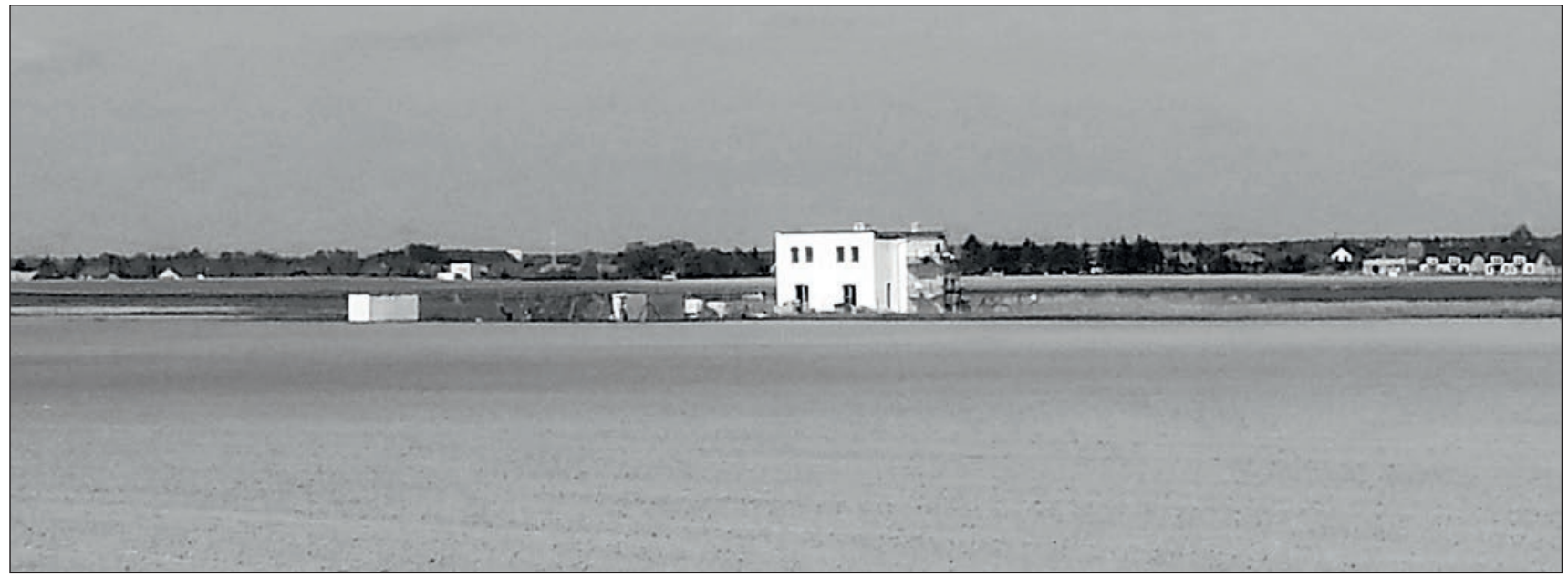

Figure 1 Single family house built in the middle of an empty field - an example of dispersion of new residential housing areas in Skórzewo Source: P. Zierke. 
(Dąbrowska-Milewska 2010: 13). Although municipalities (gminy) that belong to the Poznan Conurbation have their statutory studies of the conditions and directions of spatial development, as well as other documents that determine their spatial policy, due to conflicts of interest among different groups that try to meet their own objectives in suburban areas, such documents often contain solutions that could not be recognised as the most favourable from social interest or sustainability perspectives. The above-mentioned problems are often accompanied by the unfulfilled aspirations and needs of residents, which leads to increased criticism of complex urban structures and to questions about whether the local government authorities in suburban areas (for example bowing to pressure from developers), do not allocate too much land for development, especially residential development, compared to current needs.

Observations also confirm that the lack of imposed top-down minimum spatial requirements concerning health and social aspects leads to abuses, such as excessive housing density and limited access to basic educational, recreational, cultural, technical, and transport infrastructure. This problem was noted by the Polish Council of Architecture, the Association of Polish Architects, the Association of Polish Urban Planners, and the Polish Chamber of Architects, which have called for the introduction of urban standards that contain rules and parameters of management and the formation of new developments in line with the principles of sustainability (Polska Rada Architektury... 2011: 14).

This paper is aimed at finding a factor that would allow more accurate anticipation of the growth of built-up areas in towns and villages adjacent to large cities that are undergoing a depopulation process. It seems that a natural point of reference when studying the area of development in Skórzewo is the number of residents in that village. Unfortunately, data concerning the population of villages over the years is much more limited than the widely available information about the number of inhabitants in Poznań, for example. The same situation concerns the forecast population figures, which are given in studies carried out by the Central Statistical Office in the time horizon up to 2050 for large cities at five-yearly intervals. On the other hand, similar information is missing for small towns and villages (such data usually concerns the area of the whole municipality). Therefore, the factor that is analysed in this study is the population of Poznań, rather than that of Skórzewo. The confirmation of a close correlation between this factor and the size of built-up areas will allow the introduction a new urban planning factor that could offer a major extension of available urban planning tools. With the aid of this, the collection of more accurate information about future spatial development will be possible. More importantly, the forecasts of population growth in Poznan will allow the thesis that, as there are no central urban planning indices, excessive areas are designated for future developments in urban planning documents to be verified. During the research the following analyses and methods were used:

- Analysis of cartographic data and satellite images,

- Review of legal acts and literature on the subject,
- Correlation analysis using the Pearson linear correlation coefficient,

- The intuitive method,

- The method of forecasting using a graph with estimation of a linear trend.

The next section presents a detailed description of the research work.

\section{Studying the impact of the depopulation of Poznań on the growth of the built-up area in Skórzewo}

The thought process presented in the preceding chapter is a starting point for studying the relationship between two factors that contribute to the phenomenon of suburbanisation - the decreasing population in city centres and growing built-up areas in suburbia.

According to the author, the term 'built-up area' has to be specified, as it is widely used in this paper. Although its concept is presented in Polish legislation, its definition - to the best of the author's knowledge - is included in the Road Traffic Act only in laconic fashion and says: 'area marked with proper road signs' (Ustawa $z$ dnia 20 czerwca 1997 r. Prawo o ruchu drogowym: Article 2.15). Interestingly, the explanation of the term is also missing in the Spatial Planning and Land Development Act (Ustawa $z$ dnia 27 marca 2003 r. o planowaniu i zagospodarowaniu przestrzennym). A definition of built-up area has been introduced into the 2014 Draft of the Urban-Planning and Building Code - it is 'an area delineated in the municipality's statutory document known as the study on the conditions (i.e. existing situation) and directions (i.e. development potential) of spatial development, where existing developments are to be supplemented' (Niewiadomski et al. 2014: 7). However, the definition has been withdrawn from the current Draft of the Code (Ministerstwo Infrastruktury i Budownictwa 2016) published in 2016. For the purpose of this study, the built-up area is to be understood as land on which buildings stand. Moreover, a non-built-up area is to be understood as land with no buildings erected.

The study area is Skórzewo, a village located in the municipality of Dopiewo, in Poznan district, the first mention of which dates back to the $14^{\text {th }}$ century. It can be characterised by flat terrain, as well as a lack of larger clusters of trees (apart from the historic manor park), a lack of large surface water reservoirs and rivers (the Skórzyna stream flows through the village and the Plewianka has its source here). In the central part of Skórzewo there is a historic parish church built in 1927-1929. To the north, south and west the village is surrounded at a similar distance by dual carriageways. Part of the southern border of the village is the railway line (linking Poznan and Berlin), and the eastern border is adjacent to the city of Poznań. Due this proximity, Skórzewo, which for centuries has been a village with a rural character, is currently witnessing the disappearance of family farms and intense development of residential housing with a parallel dynamic growth in population. In 1995-2011, the number of inhabitants in the village increased by 2,961 persons, while in 1970-1995 it only increased by 306 persons (Reso- 
lution No. XVI/226/16 of Dopiewo Municipality Council of 29 February 2016 on adopting the study on the conditions and directions of spatial development in the Dopiewo municipality: 43). In 2017, the village of Skórzewo had 6,591 inhabitants, twice as many as the capital of the municipality - Dopiewo, where the growth of population was smaller, due to its greater distance from the city limits of Poznań (Liczba mieszkańców na dzień 3 kwietnia 2017 n.d.). In 2012, Skórzewo had 38 Spatial Development Plans that covered 25.7\% of the area of the village (Mrozik \& Wiśniewska 2013: 2134).

Due to the availability of cartographic data and satellite images, the study covered the years of 1990, 2000, 2003,2007, 2010,2013 , and 2015, provided that the maps were selected for analysis only if their exact date was confirmed. Moreover, attempts were made to limit the time intervals to 2-4 years, although due to the low availability of satellite images before 2000, the interval between the first and second years was 10 years. The data collected was next processed in CAD software, which permitted the determination of the approximate size of the built-up area in Skórzewo in the above-mentioned years. The built-up area is given in Tab. 1 .

Table 1 The built-up areas in Skórzewo in 1990, 2000, 2003, 2007, 2010, 2013 and 2015

\begin{tabular}{cccc}
\hline Year & Built-up area [ha] & Change [\%] & $\begin{array}{c}\text { Average annual } \\
\text { growth rate [\%] }\end{array}$ \\
\hline 1990 & 32.73 & & \\
\hline 2000 & 92.94 & $+183.96 \%$ & $+18.40 \%$ \\
\hline 2003 & 139.75 & $+50.36 \%$ & $+16.79 \%$ \\
\hline 2007 & 190.92 & $+36.62 \%$ & $+9.16 \%$ \\
\hline 2010 & 212.34 & $+11.22 \%$ & $+3.74 \%$ \\
\hline 2013 & 227.56 & $+7.17 \%$ & $+2.39 \%$ \\
\hline 2015 & 240.59 & $+5.73 \%$ & $+2.87 \%$ \\
\hline
\end{tabular}

Source: own analysis.

The growth of the built-up area in Skórzewo is presented in Fig. 2.

In the second stage of the analysis, data on the population of Poznań has been collected in the same years as the built-up areas in Skórzewo were determined. The total population of Poznań given in Tab. 2 is derived from information provided in the Local Data Bank of the Central Statistical Office (Bank Danych Lokalnych...).

Table 2 The population of Poznań in 1990, 2000, 2003, 2007, 2010, 2013 and 2015

\begin{tabular}{cccc}
\hline Year & Population & Change [\%] & $\begin{array}{c}\text { Average annual } \\
\text { growth rate [\%] }\end{array}$ \\
\hline 1990 & 590101 & & \\
\hline 2000 & 582254 & $-1.33 \%$ & $-0.13 \%$ \\
\hline 2003 & 574125 & $-1.40 \%$ & $-0.47 \%$ \\
\hline 2007 & 560932 & $-2.30 \%$ & $-0.57 \%$ \\
\hline 2010 & 555614 & $-0.95 \%$ & $-0.32 \%$ \\
\hline 2013 & 548028 & $-1.37 \%$ & $-0.46 \%$ \\
\hline 2015 & 542348 & $-1.04 \%$ & $-0.52 \%$ \\
\hline
\end{tabular}

Source: own analysis based on the Local Data Bank of the Central Statistical Office (Bank Danych Lokalnych...).

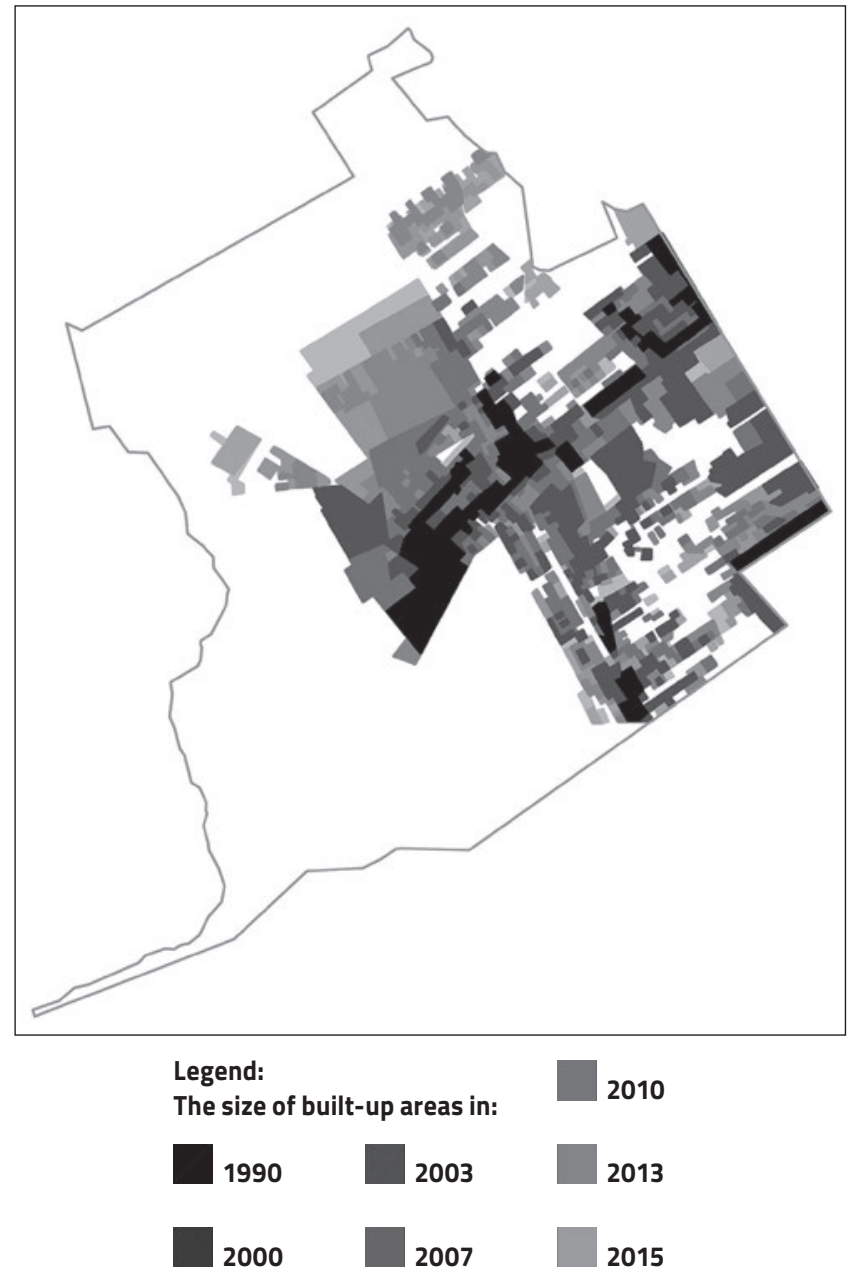

Figure 2 Development of the built-up area in Skórzewo in 1990, 2000, 2003, 2007, 2010, 2013 and 2015

Source: own analysis.

In the next stage of the analysis, the data collected was compared using the Pearson linear correlation coefficient. As a result of the examination conducted using the GraphPad InStat software, a very high value of correlation coefficient was found between the size of the built-up areas in Skórzewo and the population of Poznań, amounting to -0.98 (the values of the Pearson linear correlation coefficient amounting to $-0.5-0.0$ and $0.0-0.5$ are interpreted as weak ones, while from -1.0 to -0.5 and from 0.5 to 1.0 as strong ones). The result obtained is close to the maximum value that can be achieved in the study (-1.00 or 1.00), which means that the correlation is extremely strong. This also indicates a linear connection between the two factors analysed. A statement can be ventured that the exact correlation is the quantifiable confirmation of the existing suburbanisation process in Skórzewo and Poznań. Moreover, the close relationship can underlie more accurate forecasts of demand for built-up areas in future planning documents concerning Skórzewo according to the anticipated population figures of Poznań.

Referring to above observations, a forecast of the development of built-up areas in Skórzewo was undertaken, which based on the population forecasts of Poznań. According to the data of the Central Statistical Office, the number of inhabitants 
in the city will continue to decrease and will total 488,226 persons in 2030, 443,721 in 2040, and 402,076 in 2050 (Główny Urząd Statystyczny 2015). Forecasts are produced for periods of up to 35 years, which complies with the recommendations of the Spatial Planning and Development Act of 27 March 2003. According to the Act, when determining the demand for new developments, the forecast for a maximum of 30 years is to be taken into account as well as the uncertainty of development processes that can give an opportunity to increase the demand compared to the results of the analysis by a maximum of $30 \%$ (Ustawa $z$ dnia 27 marca 2003 r. o planowaniu i zagospodarowaniu przestrzennym: Article 10.2). Using the diagram of the relationship between the built-up areas in Skórzewo and the population of Poznań, it is possible to determine the trend lines and the connection between the forecast population and the future size of the built-up areas in the village. The forecast growth of developments is presented in the diagram (Fig. 3), where the trend line is a curved extension of the values obtained in the years analysed and follows the formula: $y=-0.7845 x^{2}-7.536 x+590700$. It should be also mentioned that the average forecast error in analyzed years was calculated at $0.0001 \%$. The low value of this factor is most likely caused by the fact that the analysis concern only seven years, but also by the low values of forecast errors, which were determined for particular analyzed years (they fluctuate between $-0.34 \%$ and $0.21 \%$ ).

The results presented in the diagram confirm that as the population of Poznan decreases, the size of the built-up area of Skorzewo increases, although both processes are gradually slowing down. If the present trend continues, the size of the built-up areas in Skórzewo analysed should be about 360 ha in 2030, about 430 ha in 2040, and about 480 ha in 2050. In- terestingly, the current total area proposed to be developed in the present Study of the conditions and directions of spatial development in Dopiewo municipality is about 510 ha (Uchwała nr XVI/226/16 Rady Gminy Dopiewo... 2016: 67). Assuming on a pro-rata base that the size of the built-up area according to this analysis will be about 460 ha 30 years after the date the study has been produced (that is, in 2046), the predictions of planners will have been exceeded by less than $11 \%$. Consequently, considering the option to increase the demand by a maximum of $30 \%$ given in the Spatial Planning and Land Development Act, the size of areas designated for development is within the legal limits. The thesis that the area of such land is disproportionate and usually inflated compared to current needs, which contributes to the spatial problems described in the introduction of this paper, is disproved with respect to Skórzewo. However a new question has to be asked if the statutory option to increase the demand by up to $30 \%$ is not exaggerated and, perhaps, should be limited to e.g. 10\%, which might enable the local authority to exercise closer supervision over the dynamically growing built-up areas and to limit the problems described extensively in the introduction above.

\section{Conclusions}

The results of the study show a strong correlation between the size of built-up areas in Skórzewo and the population of Poznań, which is a quantifiable confirmation of the existence of the suburbanisation process in the Poznan Conurbation. The close relationship provides a new planning tool for forecasting the demand for areas designated for future development. Forecasts provided by the Central Statistical Office present a continuous decrease in the population of Poznań,

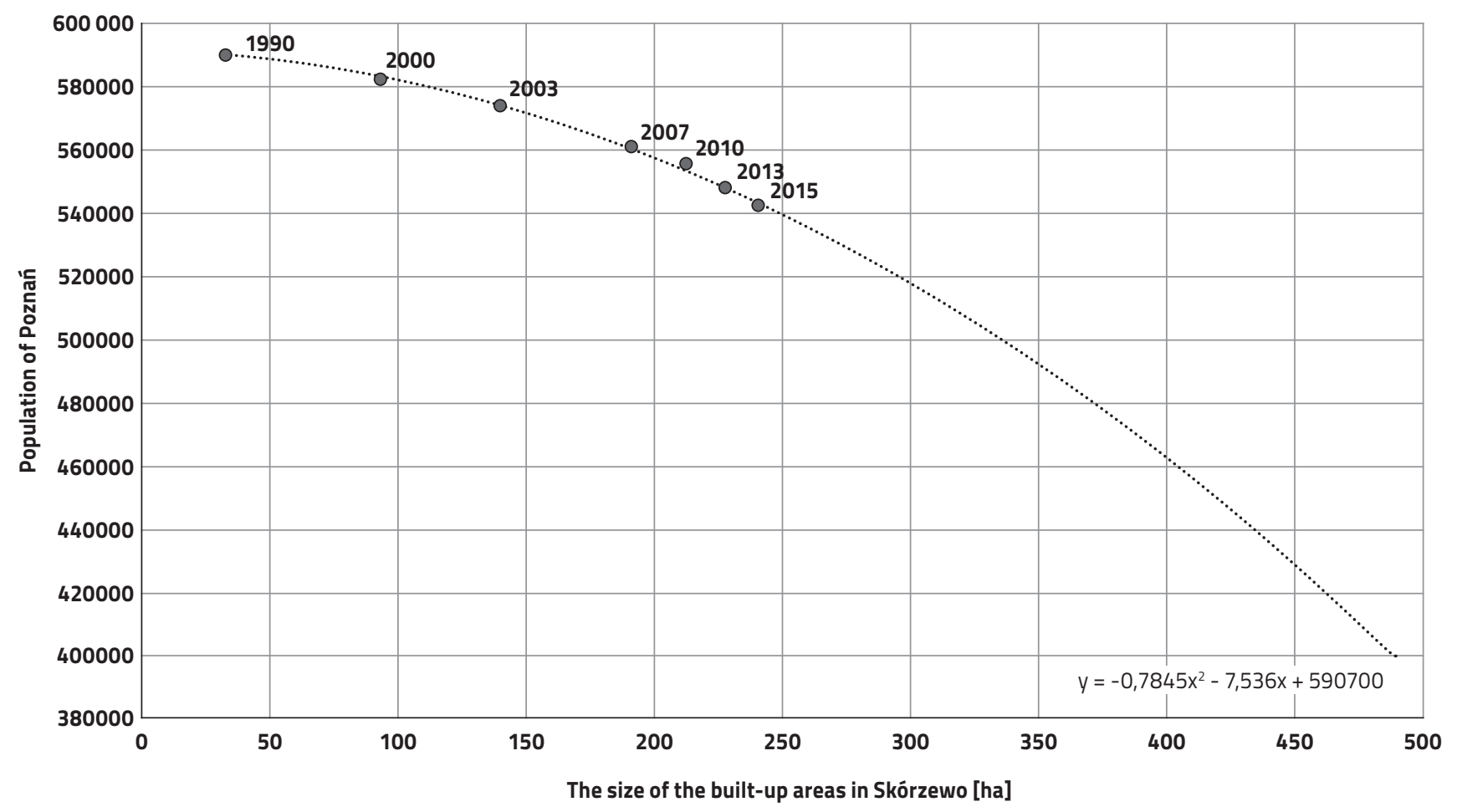

Figure 3 Forecast of the size of built-up area of Skórzewo based on forecast population figures in Poznań

Source: own analysis based on the Central Statistical Office (Główny Urząd Statystyczny 2015) data. 
while the results of the analysis described in this paper show a parallel increase in the size of the built-up area in Skórzewo, although both processes are gradually slowing down. The results of the study also indicate that the built-up area proposed in the statutory study on the conditions (i.e. existing situation) and directions (i.e. development potential) of spatial development in Dopiewo municipal area is greater than the value obtained from the analysis. According to the study, with the present depopulation trend the planned size of the built-up area will only be achieved in the mid-2050s, which will take place about 10 years after the 30 -years' temporal perspective of the municipal study. Nevertheless, in view of the statutory option to increase the demand by a maximum of $30 \%$, the size of areas designated for development in the study has been exceeded by only $11 \%$. Although this undermines the thesis that the local authorities (at least in Skórzewo) have designated too much land for development, another question has to be asked: would it be preferable to limit the potential increase of areas to not more than e.g. $10 \%$. In view of the lack of phasing of the commencement of consecutive areas for development, it might have a positive impact in restoring spatial harmony in the suburbs.
In the author's opinion, the research methods presented in this paper would also allow them to be applied in other locations, however, since the analysis was limited to the area of only one village, it is not possible at the moment to determine whether the case of Skórzewo is unique or the results could be applied in other areas. It is possible that the proposed research method will be applicable to a very narrow group of settlements in specific locations and only those with specific geographical conditions. For the above-mentioned reasons, the author intends to continue the analysis, which should cover a larger area. Confirmation of the equally strong connection between the two factors considered in other locations would strengthen the significance of the forecasting mechanism proposed in the study. In further studies the author also considers the field work methods used. It is also planned to check for possible exclusions from the correlation and to question the reasons for these. The author hopes that as a result of further work, the tool presented in this study will become an interesting planning aid, useful in determining the future development of built-up areas in regions that are subject to suburbanisation phenomena.

\section{References}

Beim, M. (2009) Modelowanie procesu suburbanizacji w aglomeracji poznańskiej, Bogucki Wydawnictwo Naukowe, Poznań [in Polish with English abstract].

Benevolo, L. (2000) Die Geschichte der Stadt, Campus Verlag, FrankfurtNew York [in German].

Berg, L. van der, Drewett, R., Klaassen, L.H., Rossi, A. \& Vijverberg, C.H.T. (1982), Urban Europe, vol. 1: A Study of Growth and Decline, Pergamon, Oxford.

Bonenberg, W. (2011) Urban sprawl jako zagrożenie tożsamości miasta, Zeszyty Naukowe Politechniki Poznańskiej. Architektura i Urbanistyka, 23, 7-14 [in Polish with English abstract].

Champion, T. (2001) Urbanization, Suburbanization, Counterurbanization and Reurbanization, [in:] Paddison, R., ed., Handbook of Urban Studies, Sage Publications, London, Thousand Oaks, New Dehli, $143-161$.

Chong, P. (2004) Understanding residential expantion using MAS/LUCC models, International Institute for Geo-Information Sciences and Earth Observation, Enschede.

Dąbrowska-Milewska, G. (2010) Czy w Polsce potrzebne są krajowe standardy urbanistyczne dla terenów mieszkaniowych, Architurae et Artibus, 1, 12-16 [in Polish with English abstract].

Duany, A., Plater-Zyberk, E. \& Speck, J. (2001) Suburban Nation: The Rise of Sprawl and the Decline of the American Dream, North Point Press, New York.

Fielding, A.J. (1982) Counterurbanisation in Western Europe, Progress in Planning, 17 (1), 1-52.

Główny Urząd Statystyczny (2015) Rocznik Statystyczny Poznania 2015, Poznań. Available from: poznan.stat.gov.pl/dane-o-wojewodztwie/ stolica-wojewodztwa-994/ludność-1154/ [14.04.2017] [in Polish].

Hall, P. (1971) Spatial structure of metropolitan England and Wales, [in:] Chisholm, M., Manners G., ed., Spatial Policy Problems of the British Economy, Cambridge University Press, Cambridge, 96-125.
Heberle, L. C. \& Opp, S. M. (2008) Local Sustainable Urban Development in a Globalized World, Ashgate Press, Aldershot, Burlington.

Hutabarat Lo, R. (2009), Walkability: what is it?, Journal of Urbanism: International Research on Placemaking and Urban Sustainability, 2 (2), 145-166. DOI: 10.1080/17549170903092867.

Klaassen, L.H., Molle, W.T.M. \& Paelinck, J. (1981) Dynamics of Urban Development, Aldershot, Gower.

Liczba mieszkańców na dzień 3 kwietnia 2017 (n.d.). Available from: https:// www.dopiewo.pl/liczba-mieszkancow/ [17.04.2017] [in Polish].

Ministerstwo Infrastruktury i Budownictwa (2016), Ustawa kodeks urbanistyczno-budowlany, Projekt z dnia 30 września 2016 r. Available from: https://legislacja.rcl.gov.pl/docs//2/12290463/12382118/12382119/dokument247655.pdf [19.04.2017].

Mrozik, K. \& Wiśniewska, A. (2013) Miejscowe plany zagospodarowania przestrzennego jako instrument zarządzania procesem suburbanizacji na terenach wiejskich na przykładzie obrębu geodezyjnego Skórzewo, Annual Set The Environmental Protection, 15, 2126 - 2141. [in Polish with English abstract].

Niewiadomski, Z., Korczak, B., Leszczyński, M. \& Łazutka, K., eds., (2014), Kodeks urbanistyczno-budowlany. Projekt, wersja podstawowa, przyjęty $w$ dniu 16 kwietnia 2014 r., Komisja Kodyfikacyjna Prawa Budowlanego, Warszawa. Available from: http://www.izbaarchitektow.pl/pliki/projekt_dniu_16_kwietnia_2014_kodeks_urbanistyczno-budowlany.pdf [19.04.2017].

Polska Rada Architektury, Stowarzyszenie Architektów Polskich, Towarzystwo Urbanistów Polskich, Izba Architektów RP (2011) Polska Polityka Architektoniczna. Polityka jakości krajobrazu, przestrzeni publicznej, architektury, Warszawa. Available from: http://www.sarp.org.pl/ pliki/ppa.pdf [20.04.2017] [in Polish].

Thünen, J.H. von (1826), Der isolirte Staat in Beziehung aufLandwirthschaft und Nationalökonomie, oder Untersuchungen über den Einfluß, den die Getreidepreise, der Reichthum des Bodens und die Abgabenauf den Ackerbau ausüben, Perthes, Hamburg [in German]. 
Uchwała nr XVI/226/16 Rady Gminy Dopiewo z 29 lutego 2016 w sprawie przyjęcia Studium uwarunkowań i kierunków zagospodarowania przestrzennego Gminy Dopiewo (2016), Urząd Gminy Dopiewo. Available from: http://dopiewo.nowoczesnagmina.pl/?a=8938 [19.04.2017] [in Polish].

Ustawa z dnia 20 czerwca 1997 r. Prawo o ruchu drogowym (DzU $1997 \mathrm{nr}$ 98 poz. 602). Available from: http://prawo.sejm.gov.pl/isap.nsf/download.xsp/WDU19970980602/U/D19970602Lj.pdf [19.04.2017] [in Polish].

Ustawa z dnia 27 marca 2003 r. o planowaniu i zagospodarowaniu przestrzennym (DzU $2003 \mathrm{nr} 80$ poz. 717). Available from: http://isap. sejm.gov.pl/DetailsServlet?id=WDU20030800717 [accessed: 19.04.2017] [in Polish].

Werner, P. (2005) Symulacja zmian zasięgu obszaru zurbanizowanego aglomeracji Warszawy, [in:] Czyż, T. \& Rogacki, H., eds., Współczesne problemy i koncepcje teoretyczne badań przestrzenno-ekonomicznych, Biuletyn KPZK PAN 219, 156-172 [in Polish with English abstract].

Wolfram, S. (1983), Statistical Mechanics of Cellular Automata, Reviews of Modern Physics, 55, 601-644.

Wolfram, S. (1986) Theory and Application of Cellular Automata, AddisonWesley, Reading, MA.

Zierke, P. (2016) Wykorzystanie dziedzictwa architektonicznego do podniesienia jakości środowiska życia człowieka na terenach podmiejskich, [in:] Januchta-Szostak, A. \& Banach, M., eds., Architektura wobec wyzwań zrównoważonego rozwoju. Tom 2, Wydawnictwo Politechniki Poznańskiej, Poznań, 147-157 [in Polish with English abstract].

\section{Internet sources}

Bank Danych Lokalnych GUS: https://bdl.stat.gov.pl [accessed: 14.04.2017] [in Polish]. 